\title{
Sustainability and Design Innovation: Thinking Inside and Outside the Box
}

\author{
Brian Burns \\ Associate Professor \\ School of Industrial Design, Carleton University \\ Ottawa \\ brian_burns_eng@carleton.ca
}

\begin{abstract}
The notion of change and growth became persistent objectives in the $20^{\text {th }}$ century, perhaps epitomised by the acceleration in competitive industrial development, the evolved significance of GDP, and the resulting proliferation of the use of the term 'Innovation'. While the field of design has, rightly or wrongly, been seen as the proponent of innovation, the fields of Engineering have often been more conservative. This paper explores the evolution, use and understanding of the term innovation and attempts to identify its potential for development of a sustainable design paradigm for the $21^{\text {st }}$ century.
\end{abstract}

\section{Introduction - Thinking outside the box}

The phrase 'Innovative Sustainability' would appear to be an oxymoron.

Unlike mankind, most of the successful species on this planet have evolved slowly with very little innovation, and we only get to admire other species' creativity when our expanding territory intrudes on theirs. A typical example might be manifest by the synthetic materials we commonly find built into animals' nests. But this isn't innovation.

The $20^{\text {th }}$ century will perhaps be known by future historians as the 'synthetic century'. The growth in the use of the term 'man-made' throughout the $20^{\text {th }}$ century is very revealing [1]. Man-made landscapes and man-made materials appeared at a startling rate; even our attempts to create breast milk that in the mid 1950s was considered far superior to natural lactation [2]. Our ambitions to master nature on every front were formidable, and, unfortunately, have helped us develop and adopt what is generally considered to be an unsustainable pattern of life, at least in North America. From the vast benefits of an array of engineering plastics developed from oil all the way to
DDT, our creativity, while considerable has now brought us full circle, threatening our economic value system and even our means of sustainable survival; and still spiders can create a material to spin their webs that is pound-for-pound stronger than Kevlar [3].

As we developed our technologic goals in line with the infinite world we thought we were living on, so too did we evolve our design and engineering professions. Change and growth became strong objectives, and the term 'innovation' can now, at the start of the $21^{\text {st }}$ century, be found in not only the design professions, but in business journals and even in government planning [4]. As a consequence, it is not surprising that for the last 30 years or so designers have been encouraged to 'think outside the box' [5]. The question is 'why'? What are we trying to find outside the box, and what are we afraid of missing out on?

The origins of the 'box' may indeed have been the familiar 9 dot square puzzle, but we have come to see it as the need to do away with unnecessary restrictions and to find another 'creative' way. But, is our objective now simply to be different or, to be better? How can we deal innovatively with both necessary and unnecessary limitations? How then should we encourage and measure the merits of 'Sustainable Innovation'?

\section{Innovation - What is special about it?}

The word 'Innovation' is defined by the Oxford English Dictionary [6] in a fairly innocuous way - a means to bring about change or to create new methods. While the need to question 'why?' remains, the word has grown to be something of a panacea - it would appear that for many, 'Innovation' is, in itself, the means to make things better.

In his book 'Building a bridge to the $18^{\text {th }}$ century', Neil Postman [7] states that the greatest invention of the $19^{\text {th }}$ century was invention itself; replacing the 
'organic evolution' that he observed had been dominant in previous times. He goes further in his explanation with:

"...the invention of invention. We learned how to invent things, and the question of why receded in importance. The idea that if something could be done, it should be done was born in the nineteenth century. And along with it there developed a profound belief in all the principles through which invention succeeds: objectivity, efficiency, expertise, standardization, measurement, a market economy, and, of course, faith in progress. As a consequence, the nineteenth century produced a massive array of startling and culturewracking inventions: telegraphy, photography, the rotary press, the telephone, the typewriter, the phonograph, the transatlantic cable, the electric light, movies, the locomotive, rockets, the steamboat, the $\mathrm{x}$ ray, the revolver, and the stethoscope, not to mention canned food, the penny press, the modern magazine, the advertising agency, the modern bureaucracy, and even (although some dispute it) the safety pin." [8]

The $20^{\text {th }}$ century brought with it an even greater array of 'culture-wracking' inventions, and closed with concerns over the proliferation of computer and communications technology; still very much immature, yet offering profound threats to the environment while being overwhelmingly adopted by every 'so-called' first, second and third world country. Yet, Postman observed that much earlier in the $20^{\text {th }}$ century...

"Among other things, the idea that progress is real, humane, and inevitable died. As early as 1932, Lewis Mumford thought progress to be "the deadest of dead ideas...the notion that has been thoroughly blasted by the twentieth-century experience".

Indeed Mumford had many notable supporters throughout the twentieth-century, to which Postman adds:

"We have been left, first, with the idea that progress is neither natural nor embedded in the structure of history; that is to say, it is not nature's business or history's. It is our business. No one believes, or perhaps ever will again, that history itself is moving inexorably toward a golden age".

"...we have held on to the idea of progress but in a form that no eighteenth century philosopher or early nineteenth - century heir of the 'Enlightenment' would have embraced - could possibly have embraced: the idea that technological innovation is synonymous with moral, social, and psychic progress."

Postman continues with his own set of questions:

"What is the problem to which this technology is the solution?"

"Which people and what institutions might be most seriously harmed by a technological solution?"
"What new problems might be created because e have solved this problem?" [9]

Our continued faith in technological solutions to the end of the $20^{\text {th }}$ century even raised questions concerning our ability to be able to cope in the increasingly complex world we have created for ourselves.

"Looking back from the year 2100, we'll see a period when our creations - technological, social, and ecological - outstripped our understanding and we lost control of our destiny. And we will think: if only - if only we'd had the ingenuity and the will to prevent some of that. I am convinced that there is still time to muster that ingenuity - but the hour is late." [10]

How then can we evoke a sense of valid innovation? History offers little support here, with many of our so-called breakthroughs coming with undesirable consequences. For example, the end of the $19^{\text {th }}$ century heralded an end to our fear of pollution and health threats due to the escalating piles of horse manure found on our city streets. The irony that the solution was found in the invention of the gas powered automobile should not go unnoticed.

\section{Innovation - A Canadian Perspective}

The Government of Canada's website offers a comprehensive section on 'Innovation in Canada'. It contains messages from the Prime Minister and the Minister for Industry, has ten sections and two appendices. Throughout its documentation the use of the term Innovation is quite ambiguous, with the implication that the key to Canada's future success lies solely in Innovation. Section 4 has the title 'An Innovation Strategy for the $21^{\text {st }}$ Century - Canada's Innovation Strategy.' It opens with:

"To address the challenges we face and become an innovation leader, Canada needs a consolidated, coordinated and aggressive plan. The Government of Canada will work with the provinces and territories, businesses, academia and others to develop a national innovation strategy for the $21^{\text {st }}$ century. As announced in the 2001 Speech from the Throne, the overall objective should be to ensure that Canada is recognized as one of the most innovative countries in the world." [11]

There are many obvious issues raised in this document. The first is that Canada does not, seven years after the 2001 Speech from the Throne, have an Innovation strategy. The documents on the site do not elaborate why Innovation is vital to the success and prosperity of Canada. Interestingly the World Economic Forum referenced in 'Section 2 - How Canada is doing in a World driven by Innovation? Canada's Innovation Strategy', states that 'Canada's 
economic prospects are significantly more promising than our current performance." [12] The connection between doing better and innovation is not clearly made, though interestingly a graph of Canada's Innovation Performance shows that in the last in the last 20 years of the 20th century the Canadian Government actually reduced its investment in Research and Development by $1 \%$.

The documents also make reference to Canada's high standard of living ( $7^{\text {th }}$ overall) with only Luxembourg and the USA surpassing Canada by a significant margin.

In looking to the future this statistic conflicts strongly with a recent global survey of national environmental impacts undertaken by the National Geographic Society [13] which put Canada second to last (just above the USA) on its 'Overall Greendex Rankings'. Clearly if Innovation is seen as a key to Canada's prosperity then that 'Innovation' needs to be focused on resolving the obvious conflicts between our environmental impacts and the long held measure of our prosperity and success, our Gross National Product.

From an innocent definition, the word Innovation has then become a term with great, yet commonly illdefined, status. On the one hand, with GNP as our yardstick, we need to develop a plan to help us 'think outside the box'. On the other hand, our environmental impacts call for us to 'get back in the box and stop fooling around'. For that we need to take a strong look at ourselves and consider the true roll of Innovation in the $21^{\text {st }}$ century and how it can be effectively integrated into our research practices and our education system.

\section{Barriers to Innovation in Engineering and Design Education}

Design and Engineering education relies on a large body of knowledge that is difficult to fit into four years of study. Simply put, it is far easier, and likely more efficient, to use tried and tested examples, year after year to educate students. However, this flies in the face of the encouragement of innovative thinking and practice. Innovation demands something new, and the challenge of open-ended problems; but with it the possibility that a solution cannot be found, and the potential for failure. Failure does not sit well with education.

\subsection{Fostering innovation through design projects}

This conference will likely hear the bemoaning of the vast quantities of time and resources required to effectively run design projects. It may well hear pleas from academics for more design work beyond a single team 'capstone' project.

The existence of CDEN is testament to the need for more design in engineering education, with the need for more time for one-on-one discussion and, of course, more resources. This is well known.

We are still learning how to foster design in engineers, and with it, how to encourage innovation. While the science of engineering can likely be best managed through lecture and problem solving projects, the question of whether design and innovation can only be managed through projects remains. Design education, particularly in the field of Industrial Design, usually has smaller classes and certainly uses design projects extensively in its curriculum. The difference lies in the types of projects undertaken. Certainly there are capstone type projects in industrial design programmes, but there are also short projects - lasting one day or even a few hours. Some projects are only partially completed to reflect one aspect of the project or the design process. Innovation is integral to the process, but Design Schools too are learning to look to the environmental consequences of their design work.

Traditional design school projects followed the pattern identified by Neil Postman as a representation of $19^{\text {th }}$ century invention - design something new, because you can! Now, design projects cannot simply be justified on a simple determination of economic viability, but also by the justification of environmental consequences, of energy use, of resource depletion, of re-manufacturability etc etc.

Joseph Fiksel perhaps describes the object of our sustainable goals best;

"A product, process or service contributes to sustainability if it constrains environmental resource consumption and waste generation to an acceptable level, supports the satisfaction of important human needs, and provides enduring economic value to the business enterprise. Note that a product cannot be sustainable in an absolute sense; rather, it must be considered in the context of the supply chain, the market, and the natural environment. Therefore, the key practical challenge of sustainable design is to understand how products, processes, and services interact with these broader systems." [14]

We now have identifiable goals, and, thanks to methods such as Life Cycle Analysis, have the means to quantify and to measure potential successes. From the open-ended perception of design as potentially irresponsible invention, we have come to a more defined goal. While this is a simplification of the interplay of many often contradictory influences we have the beginning of a new set of equations; a new 
kind of algebra. Fortunately engineers are good at algebra. Unfortunately algebra isn't Innovation, and Innovation isn't achieved simply through another form of algebra.

\subsection{Sustainable Science and Engineering}

Some five years ago a group of engineers from diverse fields, led by James Mihelcic, announced 'The emergence of a new Metadiscipline'. Their 'Sustainable Science and Engineering' spoke of the need to integrate industrial, social, and environmental processes in a global context [15]. Fundamental to their proposal was a realisation of interconnectedness across disciplines, and their proposal was not made in isolation. In the same journal that their proposal was first announced, 'Environmental Science and Technology', could be found papers on 'Designing Resilient, Sustainable Systems' and 'Applying the Principles of Green Engineering to Cradle-to-Cradle Design'.[16]

Five years since this reasonably widespread realisation for the need for sustainable engineering, and seven years since Innovation was made a key component of the Canadian Throne Speech of 2001 little has changed. Clearly the path ahead is not a simple one, but the call for innovation is clear and the direction for that innovation is now better documented.

\section{Innovation on its own is not the answer}

While the Canadian Government has been seen to give Innovation a high priority, so too have various other national government agencies in all parts of the world. Early in 2008 the US Department of Commerce announced 'steps for the federal statistics agencies and others to work to explain and quantify one of the largest and most elusive drivers of the economy innovation'. [17] The action received great support, and realised that innovation had been a key to growth in the USA.

Slightly more recently, BusinessWeek, has frequently acknowledged the trend to blame Innovation when the results of such efforts have been seen to be unsuccessful. [18] Perhaps the best rebuttal comes from Bruce Nussbaum, who simply blamed not Innovation itself, but a poor innovation process, that led to poor results. (We could perhaps exchange the word 'design' here for 'innovation'). It isn't adequate simply to innovate, but to innovate well. He adds the need always to test and prototype, adding that too often we have seen innovation praised simply because it is new and different, but just as often launched prematurely. When this is simply the failure of a piece of software, the costs can be measured in frustration, loss of time and company reputation. When failure has potentially disastrous environmental consequences, then the implications are far more serious. Some design challenges are simpler than others, and our innovation processes must reflect this.

\section{Qualifying Innovation inside and outside the box}

Jargon comes and goes. The word 'buzzword' is a 'buzzword'. To some extent the word Innovation has become something of a buzzword too. But it does have real meaning, and the need for something new is endemic to our society. The challenge is for that newness not to go unchecked or unchallenged. By itself Innovation is simply, as the Oxford English Dictionary states, the act of bringing about something new. It can just as easily be bad innovation as good innovation. Obviously, as Bruce Nussbaum suggested, the innovation process needs to be directed and managed. Just as a well-planned design process can fail due to poor designing, so too can a poorly directed Innovation process. The difference comes with the realization that in the $21^{\text {st }}$ century we might not, it many cases, need something new.

The current energy crisis is displaying two primary streams of response. On the one hand we are trying, through bio-fuels and the like, to find ways to carry on with business as usual. On the other hand we have gone beyond initial notions of sustainable energy usage to question of why we are using so much energy in the first place. Perhaps this makes a simple analogy. Doing more with less to preserve our current life styles can be seen as thinking 'inside the box'. Finding new ways to live that clearly do not manifest the future as a continuation of the past are now an essential part of our sustainable future - this requires 'thinking outside the box'.

Currently Engineers and Designers can easily find, through the developing field of Life Cycle Analysis, means to reduce costs, and perhaps to take care of emissions and pollution in response to growing legislation and increased costs. There are also a growing number of checklists to help along the way. But this is a perpetuation of the past extended, only more efficiently - 'thinking inside the box'. In 2001 Chen and Liu proposed an eco-innovative design approach using, what they termed, the TRIZ method [19]. Theirs is but one example of an essential shift in thinking 'outside the box'. The world was never the infinite planet on which we evolved our technologic and resource demanding industrial practices, and our accompanying educational curricula. Perhaps it was 
seeing the first photographs of the Earth from space that changed our awareness; perhaps it was the oil crisis of 1973 . Under 40 years to readdress the values of our technological juggernaut. Clearly we must find means to incorporate such thinking into our curricula.

We must be more selective of the battles we fight, and of their consequences. Innovation is not synonymous with design, and as such we must be wary of our use of the word. There will be time to innovate towards sustainable new methods, and a time to take stock, or to make more effective, or simply a time not to innovate. Perhaps this can be seen as playing with words, but that is not the intent. Innovation has a valuable roll to play in the $21^{\text {st }}$ century, but we must be mindful of how we use it, or it will simply become the ineffective buzzword of commerce and politicians.

\section{In Conclusion}

The term 'Innovation' is currently used too casually. Clearly it needs direction and qualification. It is not enough for something to simply be 'new', or to be 'different'. Innovation must be concerned with making things better.

We must learn how and when to introduce it into our education system, and we must learn to at least acknowledge failure (or even reward it) as part of the process.

Some problems are simpler than others, and thus innovation can be fostered more easily in tightly defined situations.

When the consequences of a problem/solution have holistic and tangible environmental consequences, through the help of evolving environmental impact tools, we can create means for measuring the quality of the innovation.

We must learn when we can or should think 'outside the box', and when we need to be creative 'inside the box'. Whether inside or outside the box we must always remember that Innovation is concerned with breaking the rules, and when we break the rules, we have to be honest.

\section{References}

[1] The Oxford English Dictionary, Volume VII, Clarendon Press, Oxford, 1989.

[2] A. Trafford and M. Kaufman, Health Talk:Infant Formula, Washington Post, Washington, June $1^{\text {st }} 1999$.

[3] J.M. Benyus, Biomimicry: Innovation Inspired by Nature, HarperCollins, New York, 1997.
[4] Government of Canada Website, Innovation in Canada, Www.innovationstrategy.gc.ca, last accessed $12^{\text {th }}$ May 2008.

[5] M. Kihn, Outside the Box: the inside story, Fast Company.com, accessed $21^{\text {st }}$ May 2008.

[6] The Oxford English Dictionary, Volume IX, Clarendon Press, Oxford, 1989.

[7] N. Postman, Building a bridge to the $18^{\text {th }}$ century; how the past can improve our future, Knopf, New York, 1999.

[8] ibid. page 39

[9] ibid. pages $40-57$

[10] T. Homer-Dixon, The Ingenuity Gap, Knopf, New York, 2000.

[11] Government of Canada Website, Innovation in Canada, www.innovationstrategy.gc.ca, last accessed $12^{\text {th }}$ May 2008

[12] ibid.

[13] National Geographic Society, Greendex Survey, Globescan, 2008.

[14] J. Fiskel, Designing Resilient, Sustainable Systems, Environmental Science and Technology, 37(23):5330-5339, American Chemical Society, Washington DC, 2003.

[15] J.R. Mihelcic, Sustainable Science and Engineering: The Emergence of a New Metadiscipline, Environmental Science and Technology, 37(23):5314-5324, American Chemical Society, Washington DC, 2003.

[16] Environmental Science and Technology, 37(23), American Chemical Society, Washington DC, 2003.

[17] Commerce News, Gutierrez calls for Government, Private Sector, and Academic Actions on Innovation Measurement, U.S. Department of Commerce, Washington DC, $18^{\text {th }}$ January 2008.

[18] B. Nussbaum, Did Innovation get a bad name at the World Economic Forum in Davos?, BusinessWeek, McGraw-Hill, New York, 29 ${ }^{\text {th }}$ January 2008.

[19] J. Chen and C. Liu, An eco-innovative design approach incorporating the TRIZ method without contradiction analysis. The Journal of Sustainable Product Design 1: 263272, Kluwer, Dordrecht, The Netherlands, 2001. 